\title{
PENERAPAN IT BALANCED SCORECARD DAN COMPETENCY GAP INDEX DALAM TATA KELOLA IT: STUDI KASUS PT. CAPELLA MEDAN
}

\author{
Hoga Saragih", Waisen², dan Bobby Reza $^{2}$ \\ ${ }^{1}$ Fakultas Teknik dan Ilmu Komputer, Universitas Bakrie \\ Kampus Kuningan, Kawasan Epicentrum, Jl. H.R. Rasuna Said Kav. C-22 Jakarta 12920. \\ ${ }^{2}$ Program Studi Magister Teknik Informatika, STMIK ERESHA \\ J1. H. Samali No.51 Kalibata Jakarta Selatan 12740. \\ Email: hogasaragih@gmail.com
}

\begin{abstract}
Abstrak
Dalam memasuki persaingan penjualan mobil dan pelayanan purna jualnya, perusahaan berusaha memanfaatkan TI sebagai alat untuk dapat memenangkan persaingan tersebut. Agar TI dapat dimanfaatkan secara maksimal dan mendukung sistem yang ada di perusahaan, dibutuhkan penilaian kinerja dari TI secara berkala. Salah satu metode untuk melakukan penilaian terhadap kinerja departemen TI adalah dengan memanfaatkan IT Balanced Scorecard sebagai tolak ukur efisiensi dalam pemanfaatan TI saat ini dan menggunakan COBIT 4.1 pada 4 (empat) domain yaitu: perencanaan dan pengorganisasian atau PO (Planning and Organization), pengadaan dan implementasi atau AI (Acquisition and Implementation), Pengantaran dan Dukungan (Delivery and Support) serta Pengawasan dan Evaluasi (Monitor and Evaluate) sebagai alat ukurnya. Dari kedua cara tersebut, peneliti mencoba untuk membuat IT Blueprint sebagai hasil akhir dari pemanfaaatan TI diperusahaan, sehingga pihak management dapat merencanakan bagaimana perkembangan TI diperusahaan untuk beberapa tahun mendatang.
\end{abstract}

Kata kunci: Tata Kelola TI, IT Blueprint, Kerangka kerja CobIT 4.1, IT Balanced Scorecard, Indekx Gap Kompetensi.

\begin{abstract}
In entering the competition car sales and after-sales service, the company tries to use IT as a tool to be able to win this competition. In order for an IT can be fully utilized and the company supports the existing system, the performance of the IT assessment is necessary periodically. One method for assessing the performance of the IT department is to utilize IT Balanced Scorecard as a measure of efficiency in the use of IT at the moment and using COBIT 4.1 to 4 (four) domains, namely: Planning and Organization (PO), Acquisition and Implementation (AI), Delivery and Support (DS), and Monitor and Evaluate (ME) as a measuring tool. From both methods, we are trying to make IT Blueprint as the end result of the utilization of IT for enterprises, so that the management can plan how the company IT development for the next few years .
\end{abstract}

Keywords: IT Governance, IT Blueprint, CobIT Framework 4.1, IT Balanced Scorecard, Competency Gap Index (CGI)

\section{Pendahuluan}

Dewasa ini mobil merupakan salah satu alat transportasi yang paling dibutuhkan oleh masyarakat Indonesia, khususnya golongan menengah dan menengah keatas. Dalam perkembangannya, penjualan mobil dan bengkel mobil merupakan salah satu bidang usaha yang paling menguntungkan, disamping bisnis yang menjanjikan tersebut, para pengusaha penjualan mobil juga tidak terlepas dari banyaknya pesaingpesaing bisnis yang ada dari tahun ke tahun. Seperti munculnya showroom-showroom dan bengkel-bengkel baru disekitar perusahaan, dengan bermunculannya persaingan dibidang usaha tersebut, tidak jarang pelanggan maupun calon pelanggan sering mengeluh. Untuk itu lah, maka perusahaan harus dapat mengambil beberapa kebijakan untuk menghadapi situasi yang ada. Terkait dengan hal ini, kesadaran dalam menyisihkan sejumlah sumber daya finansial untuk alokasi investasi IT dianggap sebagai sebuah keharusan.

PT. Capella Medan merupakan salah satu main dealer mobil Daihatsu dan bengkel resmi Daihatsu untuk wilayah Sumatera dan Aceh. Semakin cepat pertumbuhan ekonomi di Indonesia, semakin banyak pula kebutuhan orang akan mobil sebagai salah satu alat transportasi. Banyaknya persaingan yang muncul 
mengharuskan PT. Capella Medan dapat memberikan pelayanan yang lebih terhadap calon pelanggan dan pelanggannya. PT. Capella Medan mencoba memanfaatkan TI sebagai salah satu alat untuk memobilitasi penjualan dan pelayanan purna jual serta pelayanan perbaikan/reparasi mobil. Untuk dapat memanfaatkan teknologi informasi pada PT. Capella Medan secara maksimal, pihak manajemen merasa perlu untuk melakukan penilaian terhadap kinerja departemen TI dengan sebuah standar yang telah baku, sehingga teknologi informasi kedepannya dapat dipergunakan secara maksimal untuk mendukung operasional perusahaan.

Perlunya penilaian atas kinerja departemen TI pada PT. Capella Medan dikarenakan sampai hari ini kinerja departemen TI PT. Capella Medan tidak pernah diukur atau dinilai kinerjanya. Untuk itu PT. Capella Medan merencanakan sebuah rencana perkembangan TI untuk beberapa tahun mendatang. Salah satu metode yang digunakan untuk mencapai hasil tersebut adalah dengan memanfaatkan IT Balanced Scorecard sebagai tolak ukur efisiensi dalam pemanfaatan TI saat ini dan menggunakan COBIT 4.1 pada 4 (empat) domain (ITGI, 2007) yaitu: perencanaan dan pengorganisasian atau PO (Planning and Organization), pengadaan dan implementasi atau AI (Acquisition and Implementation), Pengantaran dan Dukungan (Delivery and Support) serta Pengawasan dan Evaluasi (Monitor and Evaluate) sebagai alat ukurnya. Dari kedua cara tersebut, peneliti mencoba untuk membuat IT Blueprint sebagai hasil akhir dari pemanfaaatan TI diperusahaan, sehingga pihak management dapat merencanakan bagaimana perkembangan TI diperusahaan untuk beberapa tahun mendatang.

\section{Metodologi}

Tata Kelola TI (IT governance) adalah tanggung jawab eksekutif dan dewan direksi yang terdiri dari kepemimpinan, struktur organisasi dan proses yang memastikan bahwa TI perusahaan mendukung tujuan dan strategi organisasi. Tata Kelola TI memfasilitasi agar Organisasi bisa memenuhi kualitas, bertanggung jawab dan memberlakukan berbagai persyaratan keamanan informasi sebagai suatu asset [2].

Tata kelola dan control frameworks semakin menjadi bagian yang tidak terpisahkan dalam praktek manajemen TI dan menjadi enabler dalam membentuk Tata Kelola TI comply dengan kebutuhan peraturan yang terus bertambah [1].

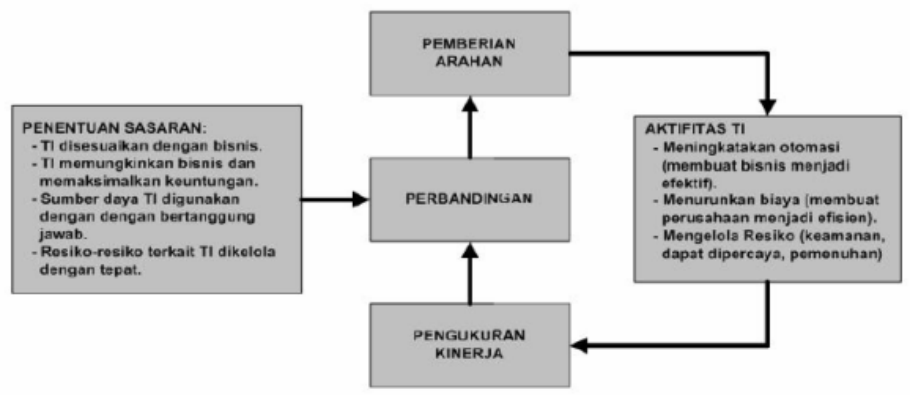

Gambar 1. Kerangka Pengendalian dan Peningkatan Berkelanjutan.

Area utama yang menjadi fokus Tata Kelola Teknologi Informasi meliputi [1]:

1. Strategic Alignment-Menghasilkan arah strategis TI dan penyelarasan TI dengan bisnis untuk mendukung pelayanan dan proyek.

2. Value Delivery-Memastikan bahwa TI atau organisasi bisnis dirancang untuk mengendalikan secara penuh keuntungan TI untuk bisnis.

3. Risk Management-Memastikan bahwa proses berjalan dengan seharusnya dan resiko dapat dikelola semestinya.

4. Resource Management-Menghasilkan arahan umum dalam pengelolaan dan pemanfaatan sumber daya TI.

5. Performance Measurement-Memantau pengukuran kinerja TI beserta kontribusi TI kedalam bisnis perusahaan.

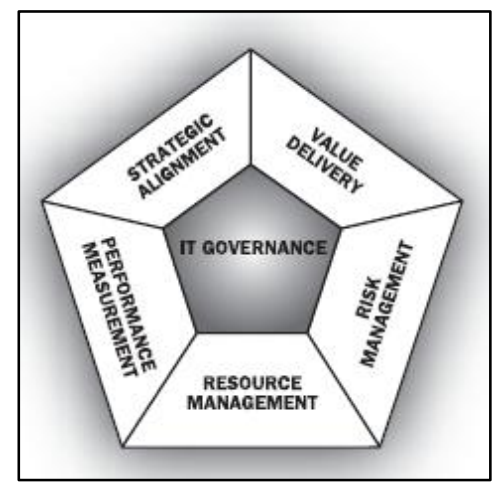

Gambar 2. Fokus Tata Kelola TI [1].

Praktek TI menjadi signifikan karena adanya faktor-faktor antara lain [1]:

1. Inisiatif Tata Kelola TI yang mengadopsi control frameworks dan praktek yang baik untuk membantu memonitor dan meningkatkan aktivitas TI yang kritis dalam meningkatkan business value dan menurunkan resiko bisnis 
2. Kebutuhan untuk optimisasi biaya dengan semaksimal mungkin mengikuti pendekatan standard daripada pendekatan yang dibangun secara khusus

3. Tingkat maturitas yang tumbuh dan penerimaan framework yang semakin dikenal baik misalnya COBIT, IT Infrastructure Library (ITIL), ISO 27000 untuk standard sekuriti informasi, ISO 9001:2000 Quality Management System, Requirements, Capability Maturity Model® Integration (CMMI), Projects in Controlled Environments 2 (PRINCE2) dan A Guide to the Project Management Body of Knowledge (PMBOK)

4. Kebutuhan perusahaan dalam mengevaluasi kinerjanya dengan benchmarking ke suatu standard yang umum dipakai.

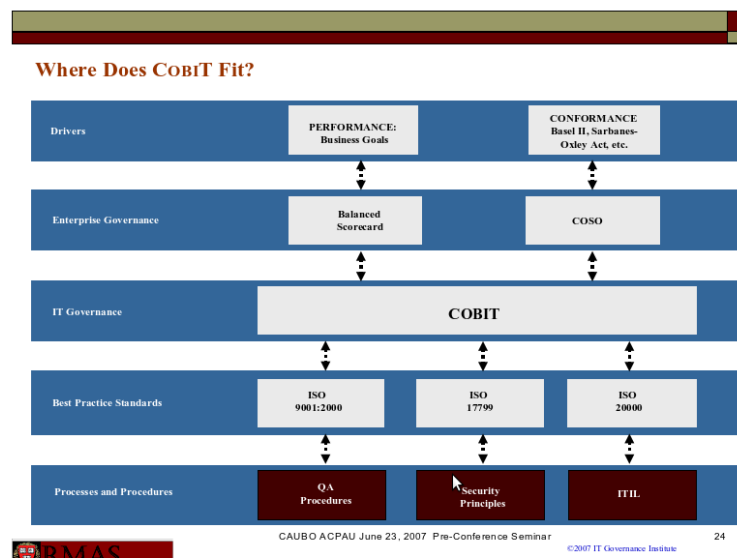

Gambar 3. Posisi praktek Teknologi Informasi [1].

Dalam mendukung Tata Kelola TI, COBIT menyediakan suatu kerangka kerja (framework) yang memastikan bahwa TI telah diselaraskan dengan bisnis, sumber daya TI telah digunakan dengan bertanggung jawab, dan resiko-resiko TI telah ditangani dengan tepat [1].

Alat yang komprehensif untuk menciptakan adanya IT Governance di organisasi adalah penggunaan CobIT (Control Objectives For Information And Related Technology) yang mempertemukan kebutuhan beragam manajemen dengan menjembatani celah antara risiko bisnis, kebutuhan kontrol, dan masalah-masalah teknis TI. Framework COBIT berlandaskan pada prinsip-prinsip seperti pada gambar 4 [1].

Kerangka kerja COBIT terdiri dari 3 level control objectives, dimulai dari level yang paling bawah yaitu activities. Activities merupakan kegiatan rutin yang memiliki konsep siklus hidup. Selanjutnya kumpulan activities dikelompokkan ke dalam proses TI (processes), kemudian proses- proses TI yang memiliki permasalahan yang sama dikelompokkan ke dalam domain (domains) [2].

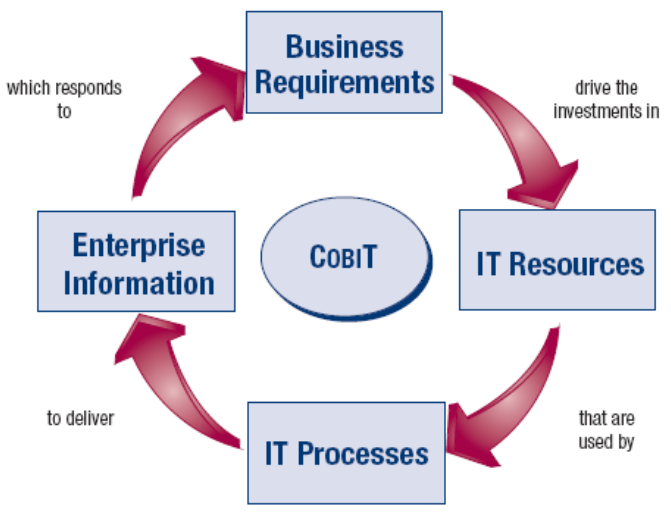

Gambar 4. Konsep dasar Framework CobIT [1].

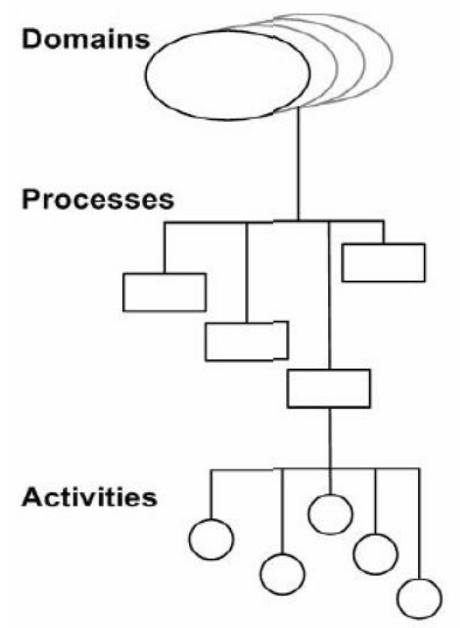

Gambar 5. Struktur Framework CobIT [1].

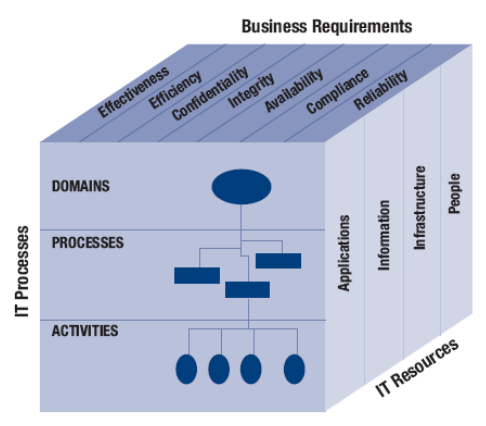

Gambar 6. Kubus CobIT [1].

CobIT Framework terdiri atas 4 domain utama:

1. Planning \& Organisation. Domain ini menitik beratkan pada proses perencanaan dan penyelarasan strategi TI dengan strategi perusahaan.

2. Acquisition \& Implementation. Domain ini menitikberatkan pada proses pemilihan, 
pengadaaan dan penerapan teknologi informasi yang digunakan.

3. Delivery \& Support. Domain ini menitikberatkan pada proses pelayanan TI dan dukungan teknisnya.

4. Monitoring\& Evaluation. Domain ini menitikberatkan pada proses pengawasan pengelolaan TI pada organisasi.

Secara keseluruhan kerangka kerja CobIT dapat dilihat pada gambar 7 .

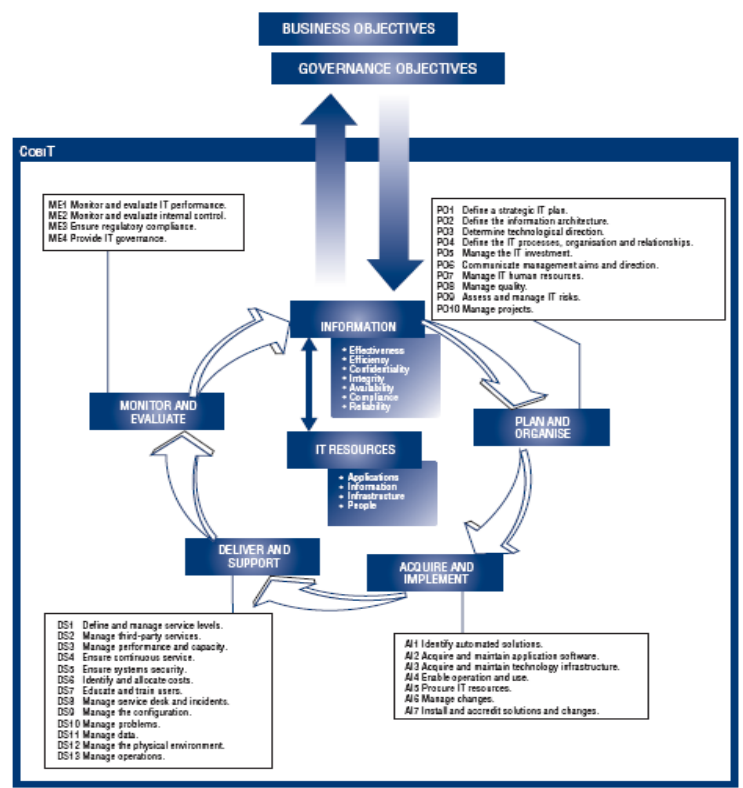

Gambar 7. Kerangka Kerja CobIT secara keseluruhan [1].

\subsection{IT Balanced Scorecard}

Konsep balanced scorecard asli, dipopulerkan oleh Harvard University profesor Robert Kaplan dan David Norton, didasarkan pada empat perspektif mendasar: keuangan, pelanggan, proses bisnis internal, serta pembelajaran dan pertumbuhan. Dengan menerapkan serangkaian spesifik tujuan, ukuran, target dan inisiatif untuk masing-masing perspektif, metode "seimbang" ini memungkinkan manajemen untuk merencanakan dan mengevaluasi berbagai bidang organisasi penting dengan pendekatan tunggal. Sebagai contoh, sebuah perusahaan menggunakan BSC bisa melacak tujuan seperti peningkatan profitabilitas (perspektif keuangan), penurunan keluhan pelanggan (perspektif pelanggan), produktivitas manufaktur ditingkatkan (perspektif proses bisnis internal) dan mengurangi perputaran karyawan (perspektif pembelajaran dan pertumbuhan).

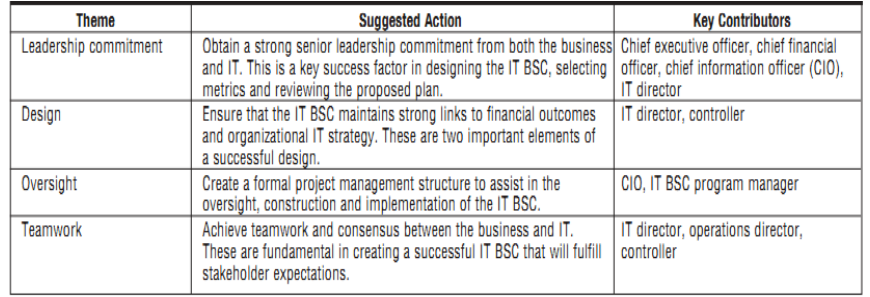

Gambar 8. Faktor kesuksesan IT BSC [4].

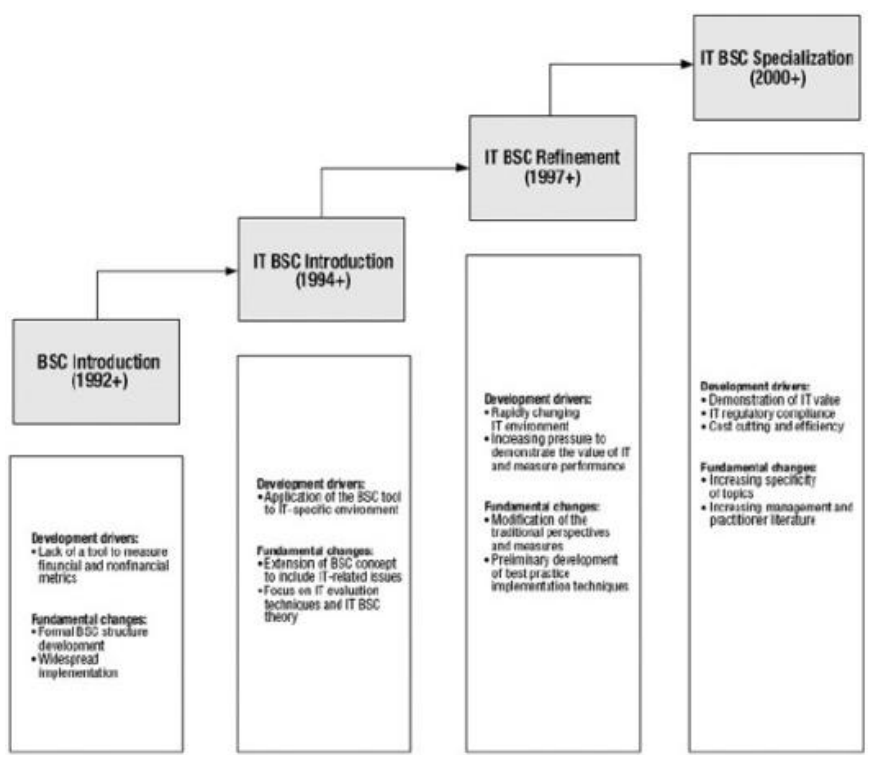

Gambar 9. Evolusi dari IT BSC [4]

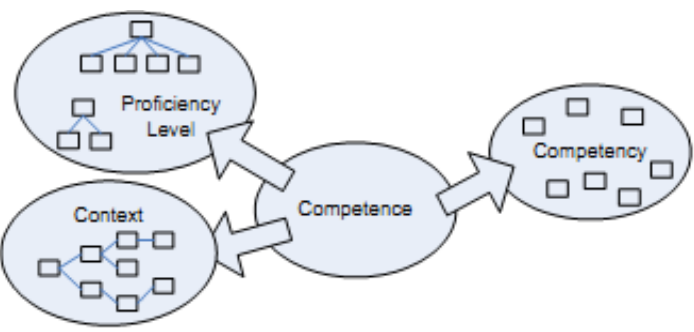

Gambar 10. Kompetensi sebagai kombinasi kompetensi tingkat kemampuan dan konteks [5].

\subsection{Competency GAP Index}

Istilah kompetensi sebagai "bentuk pengetahuan, keterampilan, sikap, kemampuan, atau tujuan pembelajaran yang dapat de-jelaskan dalam konteks pembelajaran, pendidikan atau pelatihan" [5].

Definisi yang diberikan dalam mencoba untuk memperpanjang sebelumnya: "sebuah spesifikasi, diidentifikasi, didefinisikan, dan pengetahuan yang bisa diukur, keterampilan, kemampuan, dan/atau karakteristik penyebaran 
terkait lainnya (misalnya, sikap, perilaku, kemampuan fisik) yang sumber daya manusia dapat memiliki dan yang diperlukan untuk, atau bahan untuk, kinerja dari suatu kegiatan dalam konteks bisnis yang spesifik"[6].

Definisi IEEE Kompetensi Reusable [5] menyediakan model untuk representasi kompetensi (gambar 11). Model ini tidak termasuk tingkat kemahiran atau informasi konteks. Selain itu, seperti yang dinyatakan dalam spesifikasi, IEEE RCD adalah "dimaksudkan untuk memenuhi kebutuhan sederhana referensi dan katalogisasi kompetensi, tidak mengklasifikasikan itu", yaitu, tidak menyediakan sarana untuk menentukan hubungan antara kompetensi. Hubungan tidak harus dimodelkan pada tingkat ini karena mereka juga tergantung pada dua dimensi lain: level kemahiran dan konteks. Sebagai contoh, pilot tidak dapat berhubungan dengan kompetensi lain tanpa mengetahui jika mengacu pada helikopter, pesawat kecil atau pesawat penumpang.

Model IEEE RCD untuk mewakili kompetensi (lihat model yang digambarkan dalam gambar 10).

\subsection{Gap Analysis}

Gap analysis merupakan salah satu alat yang dapat digunakan untuk mengevaluasi kinerja karyawan. Secara harfiah "gap" mengidentifikasikan adanya suatu perbedaan (disparity) antara satu hal dengan hal lainnya. Gap analysis sering digunakan di bidang manajemen dan menjadi salah satu alat yang digunakan untuk mengukur kualitas pelayanan (quality of service). Bahkan pendekatan ini paling sering digunakan di Amerika Serikat untuk memonitor kualitas pelayanan. Model yang dikembangkan oleh Parasuraman, Zeithalm dan Berry (1995) ini memiliki lima gap (kesenjangan), yaitu:

1. Gap Persepsi Manajemen

2. Gap Spesifikasi Kualitas

3. Gap Penyampaian Pelayanan

4. Gap Komunikasi Pemasaran,

5. Gap dalam Pelayanan yang dirasakan

Kita dapat membedakan antara dua jenis profil kompetensi, tergantung pada tujuan mereka:

1. Required Profil Kompetensi

2. Acquired Profil Kompetensi

Setiap jenis profil terdiri dari satu set ProfileElements. Unsur-unsur profil mungkin diperlukan atau diperoleh, tergantung pada jenis wadah profil (lihat gambar 11).

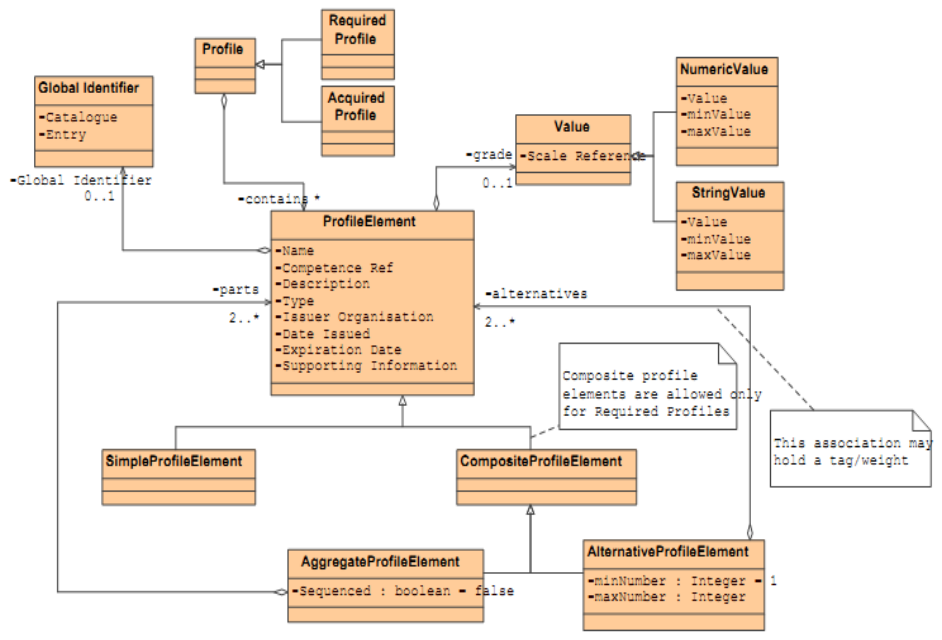

Gambar 11. Profil Kompetensi [6].

Secara singkat, gap analysis bermanfaat untuk:

1. Menilai seberapa besar kesenjangan antara kinerja aktual dengan suatu standar kerja yang diharapkan

2. Mengetahui peningkatan kinerja yang diperlukan untuk menutup kesenjangan tersebut, dan

3. Menjadi salah satu dasar pengambilan keputusan terkait prioritas dan biaya yang dibutuhkan untuk memenuhi standar pelayanan yang telah ditetapkan.

\subsection{SWOT Analysis}

Analisis SWOT adalah identifikasi berbagai faktor secara sistematis untuk merumuskan strategi perusahaan. Analisis ini dilakukan pada logika yang dapat memaksimalkan kekuatan dan peluang dan bersamaan dapat meminimalkan kelemahan dan ancaman [9].

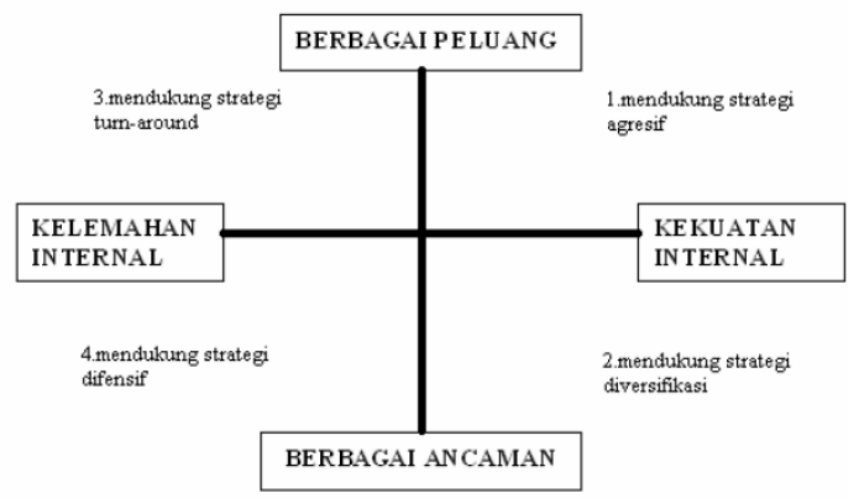

Gambar 12. Analisis SWOT [9]. 


\begin{tabular}{|l|l|l|}
\hline IFAS & $\begin{array}{l}\text { Strength (S) } \\
\text { Tentukan 5-10 faktor kekuatan } \\
\text { internal }\end{array}$ & $\begin{array}{l}\text { Weakness (W) } \\
\text { Tentukan 5-10 faktor kelemahan ir }\end{array}$ \\
\hline Opportunity (O) & $\begin{array}{l}\text { Strategi SO } \\
\text { Ciptakan strategi yang } \\
\text { menggunakan kekuatan untuk } \\
\text { memanfaatkan peluang. }\end{array}$ & $\begin{array}{l}\text { Strategi WO } \\
\text { Ciptakan strategi yang } \\
\text { meminimalkan kelemahan untuk } \\
\text { memanfaatkan peluang. }\end{array}$ \\
\hline peluang eksternal & $\begin{array}{l}\text { Strategi ST } \\
\text { Ciptakan Strategi yang } \\
\text { menggunakan kekuatan untuk } \\
\text { mengatasi ancaman. }\end{array}$ & $\begin{array}{l}\text { Strategi WT } \\
\text { Ciptakan strategi yang } \\
\text { meminimalkan kelemahan dan } \\
\text { menghindari ancaman. }\end{array}$ \\
\hline Threats (T) \\
Tentukan 5-10 faktor \\
ancaman eksternal
\end{tabular}

Gambar 13. Matriks SWOT [9].

TABEL I

EFAS (EXTERNAL FACTOR ANALYSIS SUMMARY) [7]

\begin{tabular}{|c|c|c|c|c|}
\hline $\begin{array}{l}\text { FAKTOR } \\
\text { STRATEGI } \\
\text { EKSTERNAL }\end{array}$ & $\begin{array}{l}\mathrm{B} \\
\mathrm{O} \\
\mathrm{B} \\
\mathrm{O} \\
\mathrm{T}\end{array}$ & RATING & $\begin{array}{l}\text { BOBOT } \\
\text { X } \\
\text { RATING }\end{array}$ & KOMENTAR \\
\hline PELUANG & & & & \\
\hline $\begin{array}{l}\text { TOTAL } \\
\text { PELUANG }\end{array}$ & & & & \\
\hline ANCAMAN & & & & \\
\hline $\begin{array}{l}\text { TOTAL } \\
\text { ANCAMAN }\end{array}$ & & & & \\
\hline TOTAL EFAS & & & & \\
\hline
\end{tabular}

TABEL II

IFAS (INTERNAL FACTOR ANALYSIS SUMMARY) [7].

\begin{tabular}{|c|c|c|c|c|}
\hline $\begin{array}{l}\text { FAKTOR } \\
\text { STRATEGI } \\
\text { INTERNAL }\end{array}$ & $\begin{array}{l}\mathrm{B} \\
\mathrm{O} \\
\mathrm{B} \\
\mathrm{O} \\
\mathrm{T}\end{array}$ & RATING & $\begin{array}{l}\text { BOBOT } \\
\mathrm{X} \\
\text { RATING }\end{array}$ & KOMENTAR \\
\hline KEKUATAN & & & & \\
\hline $\begin{array}{l}\text { TOTAL } \\
\text { KEKUATAN }\end{array}$ & & & & \\
\hline KELEMAHAN & & & & \\
\hline $\begin{array}{l}\text { TOTAL } \\
\text { KELEMAHAN }\end{array}$ & & & & \\
\hline TOTAL IFAS & & & & \\
\hline
\end{tabular}

\subsection{Critical Success Factor Analysis}

Analisa CSF adalah teknik yang popular dan sangat bermanfaat dalam pengembangan $I S / I T$ Strategy, dan juga pengembangan strategi bisnis [7].

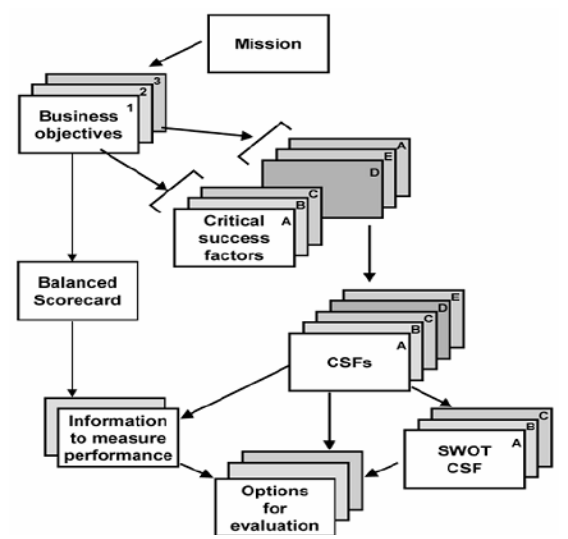

Gambar 13. Penyusunan Critical Success Factor (CSF) [7]

\subsection{Konsep Balanced Scorecard}

Dalam konsep Balanced Scorecard terdapat beberapa terminologi yaitu:

1. Visi (Vision) merupakan suatu pernyataan menyeluruh tentang gambaran ideal yang ingin dicapai oleh organisasi di masa yang akan dating.

2. Misi (Mission) merupakan suatu pernyataan bisnis dari perusahaan.

3. Sasaran (Goals) merupakan suatu pencapaian menyeluruh yang dipertimbangkan penting untuk kesuksesan organisasi di masa mendatang. Sasaran menyatakan di mana organisasi itu ingin berada di masa datang.

4. Tujuan (Objectives) menunjukkan bagaimana tindakan dan hasil-hasil yang diinginkan itu tercapai.

5. Perspektif (Perspectives) merupakan empat pandangan berbeda yang mengendalikan organisasi. Perspektif memberikan suatu kerangka kerja untuk pengukuran. Empat perspektif dalam Balanced Scorecard adalah (1) Finansial, (2) Pelanggan, (3) Proses Bisnis Internal, dan (4) Pembelajaran dan Pertumbuhan.

6. Target (Targets) merupakan suatu tingkat kinerja yang diharapkan atau peningkatan yang diperlukan di masa mendatang.

\section{Hasil dan Pembahasan}

Setelah mengidentifikasi faktor internal dan eksternal bisnis pada PT. Capella Medan, langkah selanjutnya adalah menentukan faktor faktor dari sisi internal (Internal Factor Analysis) dan eksternal (External Factor Analysis).

TABEL III INTERNAL FACTOR ANALYSIS (IFAS)

\begin{tabular}{clcccc}
\hline No & $\begin{array}{l}\text { Faktor Strategi } \\
\text { Internal }\end{array}$ & $\%$ & Jumlah & Rating & Skor \\
\hline S-1 & $\begin{array}{l}\text { Dukungan dari } \\
\text { shareholder } \\
\text { (pemegang saham) }\end{array}$ & 30 & 0.113 & 4 & 0.451 \\
S-2 & $\begin{array}{l}\text { Budaya organisasi } \\
\text { yang belum }\end{array}$ & 20 & 0.041 & 2 & 0.082 \\
S-3 & $\begin{array}{l}\text { Jaringan pemasaran } \\
\text { yang cukup luas }\end{array}$ & 30 & 0.132 & 3 & 0.397 \\
S-4 & $\begin{array}{l}\text { Sumber daya } \\
\text { manusia yang } \\
\text { harlmitim }\end{array}$ & 15 & 0.118 & 2 & 0.235 \\
S-5 & $\begin{array}{l}\text { Fasilitas untuk } \\
\text { Customer }\end{array}$ & 5 & 0.168 & 3 & 0.505 \\
\hline Total Strength (kekuatan) & 100 & 0,572 & 1.670 \\
\hline
\end{tabular}


TABEL III INTERNAL FACTOR ANALYSIS (IFAS) (CON'T)

\begin{tabular}{|c|c|c|c|c|c|}
\hline \multirow{2}{*}{ No } & \multirow{2}{*}{$\begin{array}{l}\text { Faktor Strategi } \\
\text { Internal }\end{array}$} & \multicolumn{3}{|c|}{ Bobot } & \multirow[b]{2}{*}{ Skor } \\
\hline & & $\%$ & Jumlah & Rating & \\
\hline W-1 & $\begin{array}{l}\text { Kegiatan pemasaran } \\
\text { belum maksimal }\end{array}$ & 20 & 0.102 & 3 & 0.305 \\
\hline $\mathrm{W}-2$ & $\begin{array}{l}\text { Sistem manajemen } \\
\text { yang belum } \\
\text { maksimal }\end{array}$ & 20 & 0.070 & 3 & 0.211 \\
\hline W-3 & $\begin{array}{l}\text { Kegiatan } \\
\text { operasional masih } \\
\text { ada yang manual }\end{array}$ & 40 & 0.145 & 3 & 0.436 \\
\hline W-4 & $\begin{array}{l}\text { Tidak semua outlet } \\
\text { memiliki } \\
\text { standarisasi yang } \\
\text { sama }\end{array}$ & 10 & 0.111 & 3 & 0.333 \\
\hline \multicolumn{2}{|c|}{$\begin{array}{l}\text { Total Weaknesses } \\
\text { (kelemahan) }\end{array}$} & 100 & 0,428 & & 1.284 \\
\hline \multicolumn{2}{|c|}{ Jumlah Total } & & 1 & & 0.385 \\
\hline
\end{tabular}

TABEL IV EXTERNAL FACTOR ANALYSIS (EFAS

\begin{tabular}{lcccc}
\hline \multirow{2}{*}{$\begin{array}{l}\text { Fo } \\
\text { Ekstor Strategi }\end{array}$} & $\%$ & Jumlah Rating & Skor \\
\hline $\begin{array}{l}\text { O-1 Pesaing diluar daerah } \\
\text { masih sedikit }\end{array}$ & 40 & 0.219 & 4 & 0.874 \\
$\begin{array}{l}\text { O-2 Modal yang cukup } \\
\text { besar }\end{array}$ & 30 & 0.348 & 2 & 0.696 \\
$\begin{array}{l}\text { O-3 Kebutuhan akan mobil } \\
\text { yang terus meningkat }\end{array}$ & 20 & 0.118 & 3 & 0.355 \\
$\begin{array}{l}\text { O-4 Produk bergaransi dan } \\
\text { layanan yang } \\
\text { harcandaricaci }\end{array}$ & 10 & 0.176 & 3 & 0.529 \\
\hline $\begin{array}{l}\text { Total Opportunities } \\
\text { (peluang) }\end{array}$ & 100 & 0.861 & & 2.454 \\
\hline $\begin{array}{l}\text { T-1 Persaingan industri } \\
\text { otomotif }\end{array}$ & 70 & 0.052 & 2 & 0.262 \\
$\begin{array}{l}\text { T-2 Penurunan ekonomi } \\
\text { global }\end{array}$ & 30 & 0.087 & 2 & 0.347 \\
\hline $\begin{array}{l}\text { Total Threat } \\
\text { (ancaman) }\end{array}$ & 100 & 0.139 & 0.608 \\
\hline$\quad$ Jumlah Total & & 1 & 1.845 \\
\hline
\end{tabular}

Pada analisa EFAS dan IFAS diatas, bobot diperoleh dari hasil analisa pengaruh faktor internal dan eksternal terhadap posisi strategis PT. Capella Medan, dan sedangkan rating diperoleh dari hasil penilaian terhadap faktor faktor tersebut yang dilakukan bersama-sama dengan Branch Manager dari PT. Capella Medan. Berikut perhitungan faktor eksternal dan internal berdasarkan tabel III dan tabel IV:

Titik X = Total Strength - Total Weakness

Titik $X=1,670-1,284=0,385$

Titik Y = Total Opportunities - Total Threat

Titik $Y=2,454-0,608=1,845$

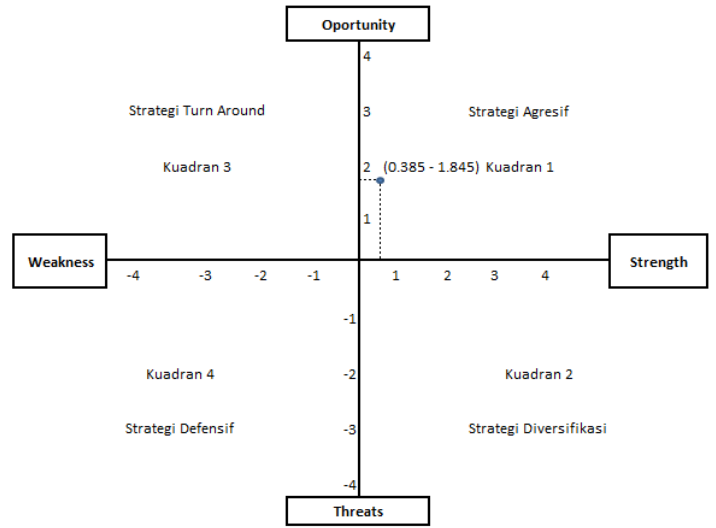

Gambar 14. Diagram SWOT PT. Capella Medan

TABEL V

MATRIK SWOT PT. CAPELLA MEDAN

\begin{tabular}{|c|c|c|}
\hline IFAS & $\begin{array}{l}\text { Strengths (S) } \\
\text { S-1 Dukungan dari } \\
\text { shareholder } \\
\text { S - 2 Budaya } \\
\text { organisasi } \\
\text { yang belum } \\
\text { terbentuk } \\
\text { S - 3 Jaringan } \\
\text { pemasaran yang } \\
\text { cukup luas } \\
\text { S - } 4 \text { Sumber daya } \\
\text { manusia yang } \\
\text { berkualitas } \\
\text { S - 5 Fasilitas untuk } \\
\text { Customer }\end{array}$ & $\begin{array}{l}\text { Weakness }(\mathbf{W}) \\
\text { W-1 Kegiatan } \\
\text { pemasaran belum } \\
\text { maksimal } \\
\text { W-2 Sistem } \\
\text { manajemen yang } \\
\text { belum maksimal } \\
\text { W-3 Kegiatan } \\
\text { operasional } \\
\text { masih ada yang } \\
\text { manual W-4 Tidak } \\
\text { semua outlet } \\
\text { memiliki } \\
\text { standarisasi yang } \\
\text { sama }\end{array}$ \\
\hline $\begin{array}{l}\text { Opportunities (O) } \\
\text { O - 1 Pesaing } \\
\text { diluar daerah } \\
\text { masih sedikit } \\
\text { O - 2 Modal yang } \\
\text { cukup besar } \\
\text { O - 3 } \\
\text { Kebutuhan } \\
\text { akan mobil } \\
\text { yang terus } \\
\text { meningkat } \\
\text { O - 4 Produk } \\
\text { bergaransi dan } \\
\text { layanan yang } \\
\text { Berstandarisasi }\end{array}$ & $\begin{array}{l}\text { Strategi SO } \\
\text { 1. Memperbaiki } \\
\text { website yang } \\
\text { terintegrasi } \\
\text { dengan } \\
\text { sistem } \\
\text { operasional (S-1, } \\
\text { O-2, O-3) } \\
\text { 2. Memudahkan } \\
\text { sistem online (S- } \\
\text { 1, S-3, S-5, O- } \\
\text { 1, O-3, O-4) } \\
\text { 3. Menambah } \\
\text { cabang di } \\
\text { daerah - daerah } \\
\text { untuk menarik } \\
\text { customer lokal } \\
\text { (S-1, S-3, O-1,O- } \\
\text { 2) }\end{array}$ & $\begin{array}{l}\text { Strategi WO } \\
\text { 1. Melakukan } \\
\text { pemasaran melalui } \\
\text { sistem online } \\
\text { (W-1, W-4, O-1, O- } \\
\text { 2, O- } \\
\text { 3) } \\
\text { 2. Melakukan } \\
\text { perancangan ulang } \\
\text { terhadap sistem } \\
\text { operasional agar dapat } \\
\text { menangani semua } \\
\text { kegiatan operasional } \\
\text { (W- } \\
\text { 3, O-2, O-3) } \\
\text { 3. Membuat aplikasi } \\
\text { sms gateway (W-1, } \\
\text { W-4, O-3, O-4) }\end{array}$ \\
\hline $\begin{array}{l}\text { Threats (T) } \\
\text { T-1 Persaingan } \\
\text { industri otomotif } \\
\text { T-2 Penurunan } \\
\text { ekonomi global }\end{array}$ & $\begin{array}{l}\text { Strategi ST } \\
\text { Membuat sistem } \\
\text { knowledge } \\
\text { management untuk } \\
\text { mendistribusikan } \\
\text { pengetahuan } \\
\text { mengenai keunggulan } \\
\text { dan kelemahan } \\
\text { produk mobil (S-1, S- } \\
4, \mathrm{~T}-1, \mathrm{~T}-4) \\
\text { Membuat sistem } \\
\text { knowledge } \\
\text { management } \\
\text { online (S-1,S-5,T- } \\
4)\end{array}$ & $\begin{array}{l}\text { Strategi WT } \\
\text { 1. Membuat sistem } \\
\text { informasi } \\
\text { manajemen resiko } \\
\text { (W-2, W-3, T-1, } \\
\text { T-4) }\end{array}$ \\
\hline
\end{tabular}


TABEL VI

HASIL REKAPITULASI PERHITUNGAN TINGKAT KEMATANGAN TI PT. CAPELLA MEDAN DOMAIN PO

\begin{tabular}{lll}
\hline \multirow{2}{*}{ Domain } & PROSES & $\begin{array}{l}\text { Hasil } \\
\text { Pengujian }\end{array}$ \\
\hline PO1 & Menetapkan Rencana Strategis & 1,032 \\
PO2 & Menetapkan Informasi Arsitektur & 1,265 \\
PO3 & Menentukan Arah Teknologi & 1,595 \\
PO4 & Mendefinisikan Proses, Organisasi & 1,343 \\
PO5 & dan Hubungan TI & 1,091 \\
PO6 & Komunikasikan Manajemen Tujuan & 1,351 \\
PO7 & Man Arah & 0,524 \\
PO8 & Mengelola sumber daya manusia TI & 0,648 \\
PO9 & Mengelola Mutu dan Menilai Resiko-resiko & 1,340 \\
PO10 & MI & 0,613 \\
\hline
\end{tabular}

Dari tabel VI tingkat kematangan (maturity level) domain dapat dibuat representasinya dalam grafik radar, seperti yang terlihat pada gambar 15 berikut ini:

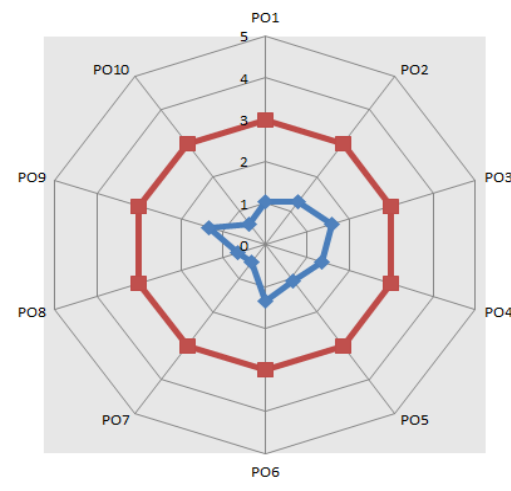

Current Maturity $=$ Expected Maturity

Gambar 15. Grafik Current maturity level vs Expected maturity level pada domain Plan and Organise $(P O)$

TABEL VII

REKAPITULASI HASIL PERHITUNGNAN TINGKAT KEMATANGAN TI DOMAIN AQUIRE AND IMPELEMNT (AI)

\begin{tabular}{|c|c|c|}
\hline Domain & PROSES & $\begin{array}{l}\text { Hasil } \\
\text { Pengujian }\end{array}$ \\
\hline AI1 & Identifikasi Solusi Otomatis & 1,310 \\
\hline $\mathrm{AI} 2$ & $\begin{array}{l}\text { Mendapatkan dan merawat aplikasi } \\
\text { software }\end{array}$ & 1,172 \\
\hline $\mathrm{AI} 3$ & $\begin{array}{l}\text { Menjaga dan Memperoleh } \\
\text { Infrastruktur Teknologi }\end{array}$ & 1,035 \\
\hline AI4 & $\begin{array}{l}\text { Memungkinkan Operasi dan } \\
\text { penggunaannya }\end{array}$ & 0,948 \\
\hline AI5 & Memperoleh Sumber Daya TI & 1,115 \\
\hline AI6 & Mengelola perubahan-perubahan & 1,415 \\
\hline AI7 & $\begin{array}{l}\text { Memasang dan mengakui solusi- } \\
\text { solusi dan perubahan-perubahan }\end{array}$ & 1,252 \\
\hline
\end{tabular}

Dari tabel VII tingkat kematangan (maturity level) domain dapat dibuat representasinya dalam grafik radar, seperti yang terlihat pada gambar 16 berikut ini:

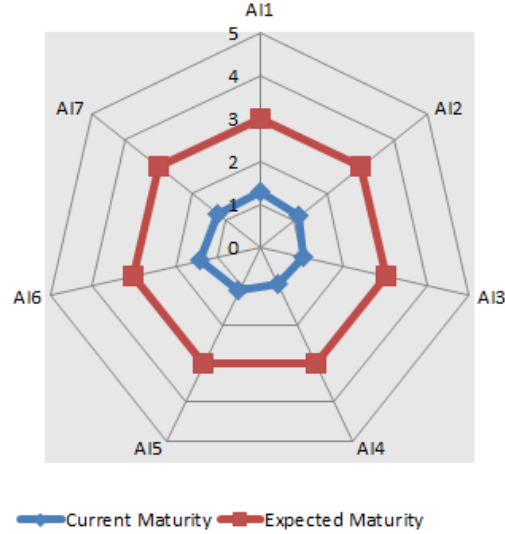

Gambar 16. Grafik Current maturity level vs Expected maturity level pada domain Aquire and Implement (AI)

TABEL VIII

REKAPITULASI HASIL PERHITUNGAN TINGKAT KEMATANGAN TI DOMAIN PENGANTARAN DAN DUKUNGAN (DELIVERY AND SUPPORT)

\begin{tabular}{lll}
\hline Domain & Proses & $\begin{array}{l}\text { Hasil } \\
\text { Pengujian }\end{array}$ \\
\hline DS1 & $\begin{array}{l}\text { Mendefinikan dan Mengelola } \\
\text { Tingkat Layanan }\end{array}$ & 1,566 \\
& $\begin{array}{l}\text { Mengelola Pelayanan dari Pihak } \\
\text { ketiga }\end{array}$ & 1,874 \\
DS3 & Mengatur Kinerja dan Kapasitas & 1,467 \\
DS4 & Menjamin Keberlangsungan & 1,440 \\
DS5 & Pelayanan & 1,005 \\
DS6 & Menjamin Keamanan Sistem & 1,774 \\
& Mengalokasikan Biaya & \\
DS7 & Memberikan Pelatihan dan Training & 2,805 \\
DS8 & pada user & 1,214 \\
DS9 & Mengelola Service Desk dan Insiden & 1,239 \\
DS10 & Mengatur Konfigurasi & 1,058 \\
DS11 & Mengatur Permasalahan & 1,148 \\
DS12 & Mengatur Lingkungan Fisik & 1,361 \\
DS13 & Mengatur Operasional & 1,489 \\
\hline
\end{tabular}

Dari tabel VIII tingkat kematangan (maturity level) domain dapat dibuat representasinya dalam grafik radar, seperti yang terlihat pada gambar 17 berikut ini:

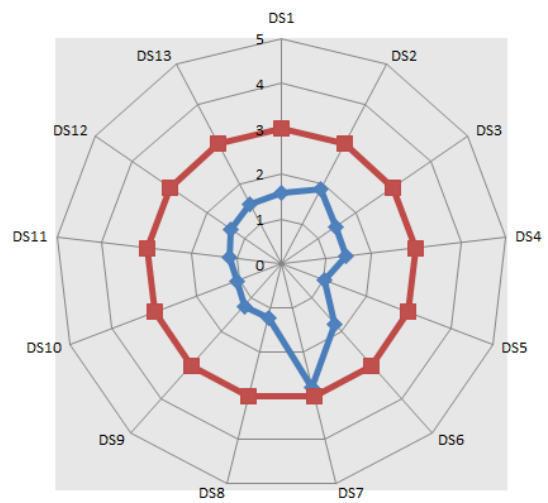

Current Maturity - Expected Maturity

Gambar 17. Grafik Current maturity level vs Expected maturity level pada domain Delivery and Support (DS) 
TABEL IX

REKAPITULASI HASIL PERHITUNGAN TINGKAT KEMATANGAN TI DOMAIN PENGAWASAN DAN EVALUASI (MONITORING DAN EVALUATE)

\begin{tabular}{cll}
\multicolumn{3}{c}{$($ MONITORING DAN EVALUATE $)$} \\
\hline Domain & Proses & $\begin{array}{l}\text { Hasil } \\
\text { Pengujian }\end{array}$ \\
\hline \multirow{2}{*}{ ME1 } & $\begin{array}{l}\text { Mengawasi dan Mengevaluasi } \\
\text { Kinerja TI }\end{array}$ & 0.973 \\
& $\begin{array}{l}\text { Mengawasi dan Mengevaluasi } \\
\text { ME2 }\end{array}$ & 1.122 \\
ME3 & Kontrol Internal & 1.224 \\
ME4 & Menjamin Kepatuhan Hukum & 0.911 \\
\hline
\end{tabular}

Dari tabel IX tingkat kematangan (maturity level) domain dapat dibuat representasinya dalam grafik radar, seperti yang terlihat pada gambar 18 berikut ini:

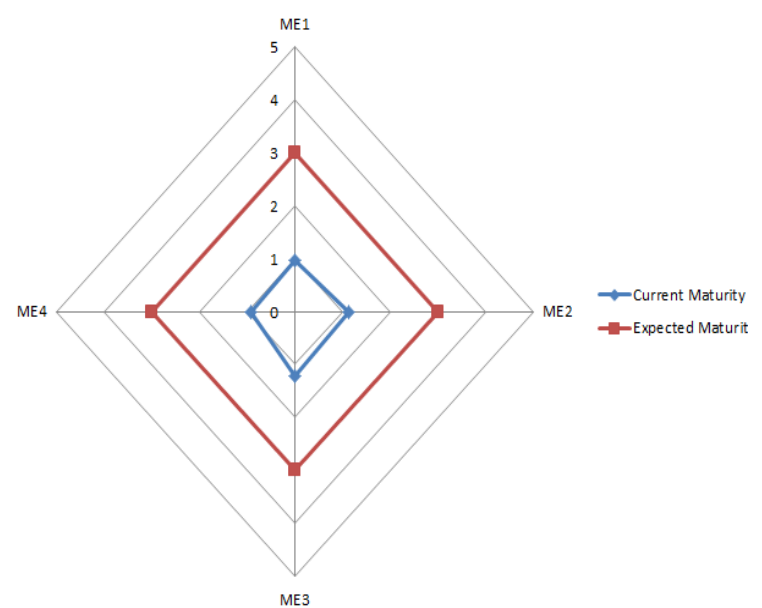

Gambar 18. Grafik Current maturity level vs Expected maturity le pada domain Monitoring and Evaluate (ME)

TABEL $X$

HASIL IMPLIKASI PENELITIAN

\begin{tabular}{|c|c|c|c|c|c|c|}
\hline $\begin{array}{c}\text { Do } \\
\text { mai } \\
\mathrm{n}\end{array}$ & PROSES & $\begin{array}{c}\text { Curre } \\
\text { nt } \\
\text { Matur } \\
\text { ity }\end{array}$ & $\begin{array}{c}\text { Expe } \\
\text { cted } \\
\text { Matu } \\
\text { rity }\end{array}$ & $\begin{array}{c}\text { Selisi } \\
h / G a \\
p\end{array}$ & \multicolumn{2}{|c|}{$\begin{array}{c}\text { Status } \\
\text { Perbaikan }\end{array}$} \\
\hline $\begin{array}{l}\mathrm{PO} \\
1\end{array}$ & $\begin{array}{l}\text { Menetap } \\
\text { kan } \\
\text { Rencana } \\
\text { Strategis }\end{array}$ & 1,032 & 3 & $\begin{array}{l}1.96 \\
8\end{array}$ & $\begin{array}{l}\text { Super } \\
\text { priori } \\
\text { tas }\end{array}$ & $\begin{array}{l}\text { Diper } \\
\text { baiki }\end{array}$ \\
\hline $\begin{array}{l}\mathrm{PO} \\
2\end{array}$ & $\begin{array}{l}\text { Menetap } \\
\text { kan } \\
\text { Informas } \\
\text { i } \\
\text { Arsitektu } \\
\text { r }\end{array}$ & 1,265 & 3 & $\begin{array}{l}1.73 \\
5\end{array}$ & $\begin{array}{l}\text { Super } \\
\text { priori } \\
\text { tas }\end{array}$ & $\begin{array}{l}\text { Diper } \\
\text { baiki }\end{array}$ \\
\hline $\begin{array}{l}\mathrm{PO} \\
3\end{array}$ & $\begin{array}{l}\text { Menentu } \\
\text { kan Arah } \\
\text { Teknolo } \\
\text { gi }\end{array}$ & 1,595 & 3 & $\begin{array}{l}1.40 \\
5\end{array}$ & $\begin{array}{l}\text { Super } \\
\text { priori } \\
\text { tas }\end{array}$ & $\begin{array}{l}\text { Diper } \\
\text { baiki }\end{array}$ \\
\hline $\begin{array}{l}\mathrm{PO} \\
4\end{array}$ & $\begin{array}{l}\text { Mendefi } \\
\text { nisikan } \\
\text { Proses, } \\
\text { Organisa } \\
\text { si dan } \\
\text { Hubunga } \\
\text { n TI }\end{array}$ & 1,343 & 3 & $\begin{array}{l}1.65 \\
7\end{array}$ & $\begin{array}{l}\text { Super } \\
\text { priori } \\
\text { tas }\end{array}$ & $\begin{array}{l}\text { Diper } \\
\text { baiki }\end{array}$ \\
\hline $\begin{array}{l}\mathrm{PO} \\
5\end{array}$ & $\begin{array}{l}\text { Mengelo } \\
\text { la }\end{array}$ & 1,091 & 3 & $\begin{array}{l}1.90 \\
9\end{array}$ & $\begin{array}{l}\text { Super } \\
\text { priori }\end{array}$ & $\begin{array}{l}\text { Diper } \\
\text { baiki }\end{array}$ \\
\hline
\end{tabular}

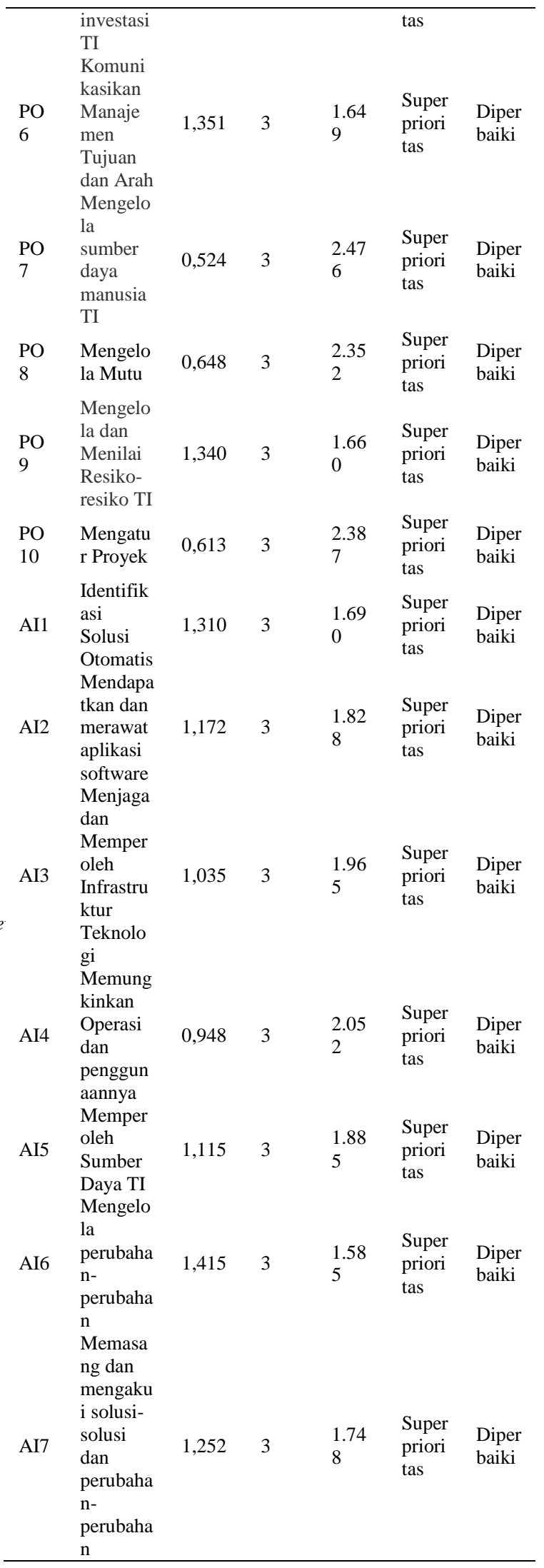


54 Journal of Information Systems, Volume 9, Issue 1, April 2013

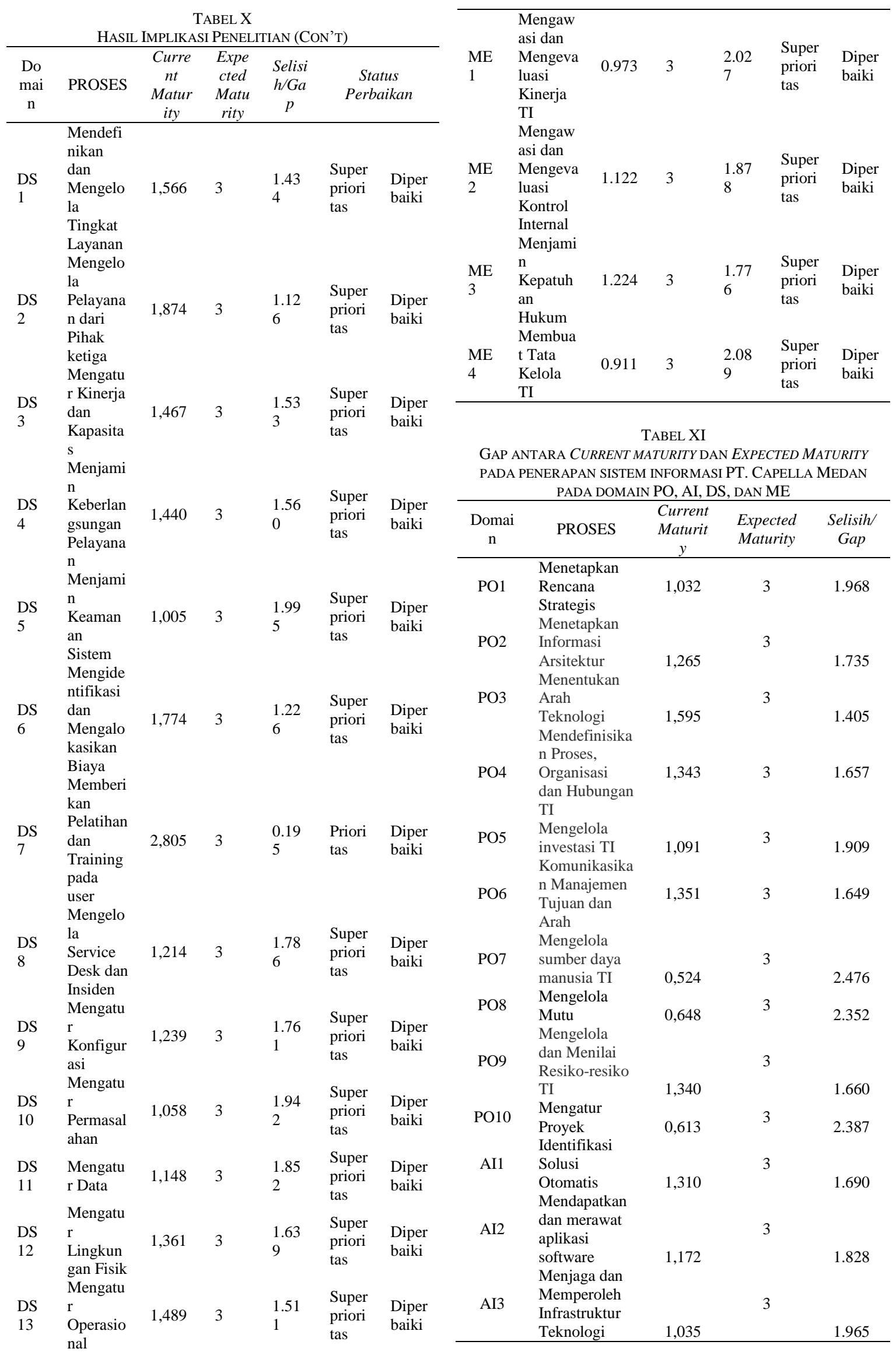


TABEL XI

GAP ANTARA CURRENT MATURITY DAN EXPECTED MATURITY PADA PENERAPAN SISTEM INFORMASI PT. CAPELLA MEDAN

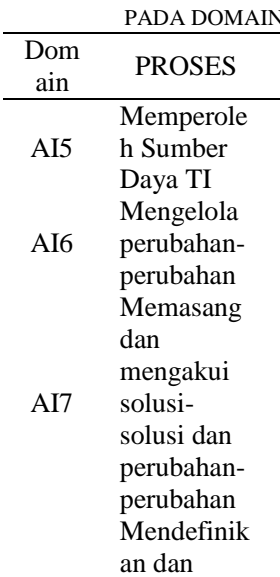

DS1 Mengelola

Tingkat

Layanan

Mengelola

DS2 Pelayanan

dari Pihak

ketiga

Mengatur

DS3 Kinerja dan

Kapasitas

Menjamin

DS4 Keberlangs

ungan

Pelayanan

Menjamin

DS5 Keamanan

Sistem

Mengidenti

DS6 fikasi dan

Mengaloka

sikan Biaya

Memberika

n Pelatihan

DS7 dan

Training

pada user

Mengelola

DS8 Service

Desk dan

Insiden

Mengatur

DS9 Konfiguras i

Mengatur

DS1 Permasalah

an

DS1 Mengatur

1 Data

DS1 Mengatur

2 Lingkunga

n Fisik

DS1 Mengatur

3 Operasiona

1

Mengawasi

dan

ME1 Mengevalu

asi Kinerja

TI

Mengawasi

1,252 , AI, DS, DAN ME (CON'T)$$
\text { (1) }
$$

3

1,467

3

3

1,440

1.560

1,005

3

1.995

3

1,774

1.226

2,805

0.195

3

1,239

1,058

1,148

1,361

1.761

3

1.942

3

3

1,489

1.639

3

3

0.973

2.027

\begin{tabular}{ccc}
$\begin{array}{c}\text { Current } \\
\text { Maturity }\end{array}$ & $\begin{array}{c}\text { Expected } \\
\text { Maturity }\end{array}$ & $\begin{array}{c}\text { Selisih/ } \\
\text { Gap }\end{array}$ \\
\multirow{2}{*}{1,115} & 3 & \\
& & 1.885 \\
1,415 & 3 & 1.585
\end{tabular}

\begin{tabular}{|c|c|c|c|c|}
\hline & $\begin{array}{l}\text { Mengevalu } \\
\text { asi Kontrol } \\
\text { Internal }\end{array}$ & & & \\
\hline \multirow[t]{3}{*}{ ME3 } & $\begin{array}{l}\text { Menjamin } \\
\text { Kepatuhan }\end{array}$ & & \multirow[t]{3}{*}{3} & \\
\hline & Hukum & 1.224 & & 1.776 \\
\hline & Membuat & & & \\
\hline \multirow[t]{2}{*}{ ME4 } & Tata Kelola & & \multirow[t]{2}{*}{3} & \\
\hline & TI & 0.911 & & 2.089 \\
\hline
\end{tabular}

RESUME CURRENT MATURITY PADA PENERAPAN SISTEM INFORMASI PT. CAPELLA MEDAN PADA DOMAIN PO, AI, DS,

\begin{tabular}{lccccc}
\multicolumn{7}{c}{ DAN ME } \\
$\begin{array}{lccccc}\text { MATURITY } \\
\text { LEVEL }\end{array}$ & PO & AI & DS & ME & \begin{tabular}{c} 
PO, AI, \\
DS, \\
\cline { 2 - 6 }
\end{tabular} \\
\cline { 2 - 6 } DE \\
\hline Expected & 3 & 3 & 3 & 3 & 3 \\
Rata-rata & 1.080 & 1.178 & 1.495 & 1.058 & 1.203 \\
Minimal & 0.524 & 0.948 & 1.005 & 0.911 & 0.524 \\
Maksimal & 1.595 & 1.415 & 2.805 & 1.224 & 2.805 \\
\hline
\end{tabular}

1.786

1.852
TABEL XIII

PENENTUAN SASARAN STRATEGIS

\begin{tabular}{|c|c|}
\hline Perspektif Kontribusi Perusahaan & $\begin{array}{l}\text { Sasaran } \\
\text { Strategis }\end{array}$ \\
\hline \%Kinerja sesuai dengan SLA & $85 \%$ \\
\hline $\begin{array}{l}\text { \% Investasi Infrastruktur dari anggaran } \\
\text { perusahaan }\end{array}$ & $50 \%$ \\
\hline \%Dampak TI bagi perusahaan & $85 \%$ \\
\hline $\begin{array}{l}\text { Index dampak penggunaan aplikasi } \\
\text { terhadap kemudahan } \\
\text { Pekerjaan }\end{array}$ & 4 \\
\hline $\begin{array}{l}\text { \%Perubahan/Pengembangan yang } \\
\text { sesuai dengan kebutuhan }\end{array}$ & $80 \%$ \\
\hline & Sasaran \\
\hline Perspektif Orientasi Pengguna & Strategis \\
\hline$\%$ Tingkat keluhan user & $20 \%$ \\
\hline $\begin{array}{l}\text { Index keuntungan menggunakan } \\
\text { aplikasi }\end{array}$ & 3.5 \\
\hline Index user Friendly & 3.5 \\
\hline Index fungsi aplikasi & 3.5 \\
\hline Index pengetahuan user tentang TI & 3.5 \\
\hline Jumlah pelatihan kepada & 6 kali \\
\hline 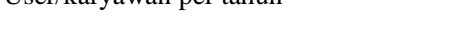 & Sasaran \\
\hline Perspektif Penyempurnaan Operasional & Strategis \\
\hline $\begin{array}{l}\text { Index penggunaan waktu kerja Divisi } \\
\text { IT }\end{array}$ & 3.5 \\
\hline Pelaksanaan pemeliharaan TI & 1 kali / bulan \\
\hline Index kebutuhan user yang terpenuhi & 3.5 \\
\hline Jumlah proyek TI baru & $1 \mathrm{kali} /$ tahun \\
\hline $\begin{array}{l}\text { \%Infrastruktur TI yang rusak atau } \\
\text { expired }\end{array}$ & $10 \%$ \\
\hline & Sasaran \\
\hline Perspektif Orientasi Masa Depan & Strategis \\
\hline Pelaksanaan backup data perusahaan & Setiap hari \\
\hline $\begin{array}{l}\text { Index prosedur Disaster Recovery } \\
\text { System }\end{array}$ & 3.5 \\
\hline Tingkat pendidikan & S2 \\
\hline Index pengalaman Staf TI & 4 Tahun \\
\hline Index waktu belajar Staf TI / Pelatihan & 3.5 \\
\hline Jumlah Staf TI yang ada & 7 \\
\hline
\end{tabular}




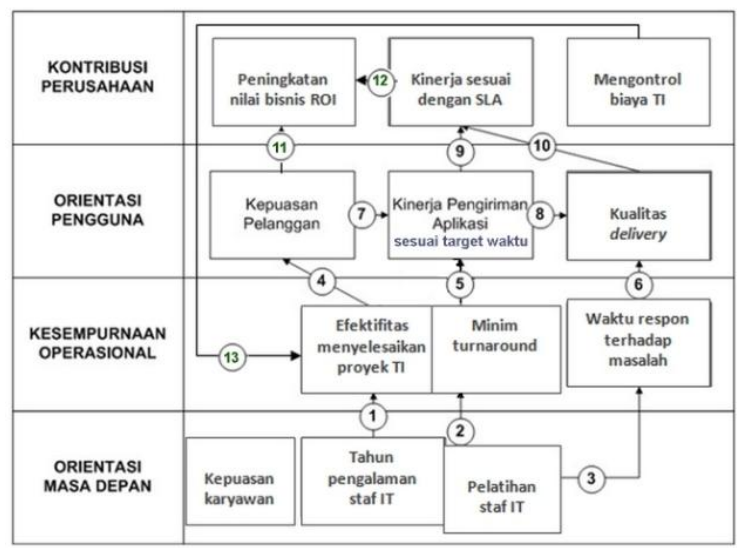

Gambar 19. Peta Strategi TI PT. Capella Medan

\begin{tabular}{|c|c|c|c|c|c|c|c|c|}
\hline \multicolumn{9}{|c|}{$\begin{array}{c}\text { TABEL XIV } \\
\text { KPI }\end{array}$} \\
\hline \multirow{2}{*}{$\frac{\text { KPI }}{\text { Orientas Penpoguna }}$} & \multirow{2}{*}{ Target } & \multirow{2}{*}{ Realisasi } & \multirow{2}{*}{ Score } & \multicolumn{5}{|c|}{ Tabel Score } \\
\hline & & & & 1 & 2 & 3 & 4 & 5 \\
\hline 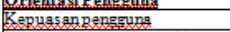 & 4 & 2 & 2 & $0-1$ & $1-2$ & $2-3$ & $3-4$ & $4-5$ \\
\hline Kinerjia Pensiriman Aplikgsi & & & & & & & & \\
\hline - Kyalitas deliveny & $90 \%$ & $80 \%$ & 3 & $=60 \%$ & $\begin{array}{l}60 \%- \\
79 \%\end{array}$ & \begin{tabular}{c|c}
$80 \%$ \\
$89 \%$
\end{tabular} & $\begin{array}{l}90 \%- \\
95 \%\end{array}$ & $-95 \%$ \\
\hline $\begin{array}{l}\text { - Delivery aplikasi } \\
\text { sessugi bud gat }\end{array}$ & $90 \%$ & $75 \%$ & 2 & $=60 \%$ & $\begin{array}{l}60 \%- \\
79 \%\end{array}$ & \begin{tabular}{c|}
$80 \%$ \\
- \\
$89 \%$
\end{tabular} & $90 \%-$ & $-95 \%$ \\
\hline $\begin{array}{l}\text { - Delivery aplikasi } \\
\text { sespusi target walth }\end{array}$ & $90 \%$ & $80 \%$ & 3 & $\leqslant 60 \%$ & $\begin{array}{l}60 \%- \\
79 \%\end{array}$ & $\begin{array}{c}30 \% \\
89 \%\end{array}$ & $\begin{array}{l}90 \%- \\
95 \%\end{array}$ & $=95 \%$ \\
\hline \multicolumn{9}{|l|}{\begin{tabular}{|l} 
Kontribusi.Perusahaan \\
Nilai Bisnis IT
\end{tabular}} \\
\hline $\begin{array}{l}\text { Peningkstan nilai } \\
\text { bisnis dari ROI }\end{array}$ & $40 \%$ & $15 \%$ & 2 & $=10 \%$ & $\begin{array}{l}10 \%- \\
20 \%\end{array}$ & \begin{tabular}{|l|}
$21 \%$ \\
$30 \%$
\end{tabular} & $\begin{array}{l}31 \% \text { - } \\
40 \%\end{array}$ & $-40 \%$ \\
\hline $\begin{array}{l}\text { Kinerjia sesuai } \\
\text { dengsan SLA }\end{array}$ & $85 \%$ & $20 \%$ & 2 & $=20 \%$ & $\begin{array}{l}20 \%- \\
50 \%\end{array}$ & $\begin{array}{c}51 \% \\
-5 \%\end{array}$ & $\begin{array}{l}76 \%- \\
90 \%\end{array}$ & $=90 \%$ \\
\hline Mengoptrol Biaya TI & $10 \%$ & $10 \%$ & 3 & $>16 \%$ & $\begin{array}{l}13 \%- \\
16 \%\end{array}$ & \begin{tabular}{|l|}
$9 \%-$ \\
$12 \%$
\end{tabular} & $\begin{array}{l}5 \%- \\
8 \%\end{array}$ & $<5 \%$ \\
\hline \multicolumn{9}{|l|}{ Kesempurnaan_Onerasional } \\
\hline 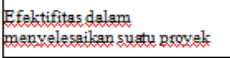 & $90 \%$ & $75 \%$ & 2 & $=50 \%$ & $50 \%-$ & $\begin{array}{c}76 \% \\
85 \%\end{array}$ & $\begin{array}{l}86 \%- \\
95 \%\end{array}$ & $>95 \%$ \\
\hline \multicolumn{9}{|l|}{ 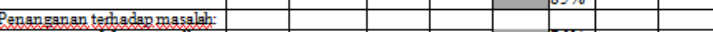 } \\
\hline $\begin{array}{l}\text { - Drempinats } \\
\text { Rrosess } \\
\text { turnaround }\end{array}$ & $90 \%$ & $55 \%$ & 3 & $<50 \%$ & $50 \%-$ & \begin{tabular}{c|}
$76 \%$ \\
$85 \%$
\end{tabular} & $\begin{array}{l}96 \%- \\
95 \%\end{array}$ & $-95 \%$ \\
\hline $\begin{array}{l}\text { - Walthy respon } \\
\text { terhadap masalah }\end{array}$ & 3 hasi & 2 hari & 4 & $\begin{array}{l}>7 \\
\text { hari }\end{array}$ & $\begin{array}{l}6-7 \\
\text { hari }\end{array}$ & \begin{tabular}{|l|}
$\begin{array}{c}0 \\
4-5 \\
\text { hari }\end{array}$ \\
\end{tabular} & $\begin{array}{l}2-3 \\
\text { hari }\end{array}$ & 1 hari \\
\hline \multicolumn{9}{|l|}{$\begin{array}{l}\text { OrientasiMasas Denan } \\
\text { Keghlian staf IT }\end{array}$} \\
\hline - Pelatihan staf IT & $50 \%$ & $10 \%$ & 1 & $=25 \%$ & $25 \%-$ & \begin{tabular}{|l|}
$50 \%$ \\
$-7 \%$ \\
$4 \%$
\end{tabular} & $\begin{array}{l}75 \% \text { - } \\
90 \%\end{array}$ & $-90 \%$ \\
\hline 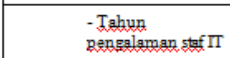 & $\begin{array}{c}4 \\
\text { tahun }\end{array}$ & 2 tahun & 2 & $\begin{array}{c}<1 \\
\text { tahun }\end{array}$ & $\begin{array}{l}1-3 \\
\text { tahun }\end{array}$ & $\mid \begin{array}{l}4-6 \\
\operatorname{tanu} \\
n\end{array}$ & $\begin{array}{l}7-9 \\
\text { tahun }\end{array}$ & \begin{tabular}{|c|}
$>9$ \\
tghun
\end{tabular} \\
\hline Kepuasan karygyag & 4 & 1 & 2 & $0-1$ & $1-2$ & $\frac{s}{2-3}$ & $3-4$ & $4-5$ \\
\hline
\end{tabular}

TABEL XV

PERHITUNGAN NILAI TOTAL IT BSC

\begin{tabular}{|c|c|c|c|c|}
\hline & KPI & Bobot & Score & Total \\
\hline \multicolumn{5}{|c|}{ Orientasi Pengguna } \\
\hline KPI 1 & Kepuasan pengguna & 0.108 & 2 & 0.216 \\
\hline $\begin{array}{ll}\text { KPI2 } \\
\text { KIT3 }\end{array}$ & 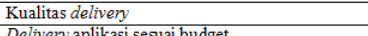 & 0.107 & 3 & 0.321 \\
\hline KPI 4 & Delivery aplikasi sesua target waktu & 0.081 & 3 & 0.244 \\
\hline \multicolumn{5}{|c|}{ Kontribusi Perusahaan } \\
\hline$\overline{\text { KPI5 }}$ & Peningkatan nilai bisnis dari ROI & 0.078 & 2 & 0.155 \\
\hline & $\begin{array}{l}\text { Kinerja sesuai dengan SLA } \\
\text { Mengontrol BiavaTI }\end{array}$ & 0.088 & $\frac{2}{3}$ & $\frac{0.175}{0.239}$ \\
\hline & Mengontrol Biaya TI & 0.080 & 3 & 0.239 \\
\hline \multicolumn{5}{|c|}{ Kesempurnaan Operasional } \\
\hline KPI 8 & Efektifitas dalam menyelesaikan suatu proyek TI & 0.071 & 2 & 0.142 \\
\hline KPI9 & Meminimalkan proses tumaround & 0.069 & 2 & 0.137 \\
\hline KPI 10 & Waktu respon terhadap masalah & 0.059 & 3 & 0.176 \\
\hline \multicolumn{5}{|c|}{ Orientasi Masa Depan } \\
\hline KPI 11 & Pelatihan staf IT & 0.055 & 1 & 0.055 \\
\hline KPI 12 & Tahun pengalaman staf IT & 0.052 & 2 & 0.104 \\
\hline \multirow[t]{2}{*}{ KPI 13 } & Kepuasan karyawan & 0.054 & 2 & 0.107 \\
\hline & TOTAL & 1.000 & & 2.272 \\
\hline
\end{tabular}

TABEL XVI TOTAL SCORE PERSPEKTIF IT BSC

\begin{tabular}{ll}
\hline Perspektif & Score \\
\hline Kesempurnaan Operasional & 0.981 \\
Orientasi Masa Depan & 0.570 \\
Orientasi Pengguna & 0.455 \\
Kontribusi Perusahan & 0.266 \\
\hline
\end{tabular}

\section{Kesimpulan}

Dari hasil analisis dan perencanaan strategis sistem informasi pada PT. Capella Medan, dapat diambil simpulan sebagai berikut:

1. Berdasarkan hasil pengukuran tingkat maturitas IT pada PT. Capella Medan dengan menggunakan kerangka kerja CobIT 4.1, didapatkan tingkat maturitas masih berada dibawah standar yang telah ditentukan yaitu masih berada pada level lebih kecil dari 3. Artinya tingkat maturitas tata kelola TI pada PT. Capella Medan masih banyak perlu perbaikan.

2. Berdasarkan analisis yang dihasilkan dari penggunaan IT Balanced Scorecard dan proses penyusunan indikasi melalui Key Performance Indikator (KPI) pada PT. Capella Medan didapatkan masih banyak kekurangan terutama pada bagian dukungan perusahaan untuk perkembangan TI pada perusahaan masih sangat minim. Selain itu juga, PT Capella Medan juga perlu meningkatkan penggunaan SI/TI untuk mendukung strategi bisnis perusahaan serta memiliki sebuah sistem informasi baru agar visi dan misi perusahaan dapat tercapai.

3. Berdasarkan hasil analisa gap yang diperoleh, didapatkan jarak gap semuanya berada pada level diatas 1 , hal ini berarti masih banyak yang harus diperbaiki oleh PT. Capella Medan dan harus secepat mungkin tindakan perbaikannya.

Hal ini dapat dikatakan secara menyeluruh proses tata kelola TI di PT. Capella Medan belum memenuhi standar internasional sesuai dengan yang ditetapkan oleh CobIT (Control Objectives for Information and related Technology) dalam tata kelola teknologi informasi.

\section{Referensi}

[1] IT Governance Institue, 2003, IT Governance Implementation Guide ; "How do I use COBIT to implement IT governance?", IT Governance Institute, http://www.isaca.org.

[2] U. Tresna Lenggana, 2007, Perancangan Model Tata Kelola Teknolog informasi pada PT. Kereta Api Indonesia Berbasis 
Framework COBIT, Institut Teknologi Bandung, Bandung.

[3] COBIT Steering Committee and the IT Governance Institute, 2000, COBIT $\left(3^{\text {rd }}\right.$ Edition) Implementation Tool Set, IT Governance Institute, http://www.isaca.org.

[4] Alec Cram, CISA, CISSP (2007), The IT Balanced Scorecard Revisited, Information System Journal Control, Volume 3, 2007

[5] IEEE RCD (2005). IEEE 1484.20.1/draft draft stan-dard for Reusable Competency Definitions (RCD).

http://www.ieeeltsc.org:8080/Plone/working- group/competency-data-standards-workinggroup-20/IEEE_1484.20.1.D8.pdf.

[6] HR-XML (2004). HR-XML Measurable Competencies. http://www.hr-xml.org.

[7] John Ward and Joe Peppard, Strategic Planning For Information System, Third Edition (2002)

[8] Kaplan R, Norton D. 1996. The Bal anced Scorecard:Translating Strategies into Action. Harvard Business School Press: Boston, MA.

[9] Rangkuti, F. 2009. Analisis SWOT Teknik Membedah Kasus Bisnis. Jakarta: PT. Gramedia Pustaka Utama. 